\title{
Social Media in Social Organization
}

\author{
Aylin Yildirim Aykurt (PhD Student) \\ İstanbul Sabahattin Zaim University, Turkey \\ Elif Sesen (Assist. Prof.) \\ Nigde Omer Halisdemir University, Turkey
}

doi: 10.19044/esj.2017.v13n20p1 URL:http://dx.doi.org/10.19044/esj.2017.v13n20p1

\begin{abstract}
As global integration process creates changes and new problem areas around individuals, people try to apply new ways for resilience. One of the methods used in this frame is social organization. Also, one of the most important tools of social organization in today's world is social media which emerge as a result of new communication technologies. The aim of this study is to reveal the role of social media in organizing society. In this context, social organization and social media were primarily defined. Some examples of the use of social media in social action and social organization have been emphasized. Data for the study was collected by using an online questionnaire. Research population of the study was Facebook users in Turkey. The sample of the study uses the convenience incidental sampling. The opinions about the role of social media in the social organization of Facebook users were examined. According to the results of the study, $72 \%$ of the participants agree that social media is a powerful tool in organizing social actions. $40 \%$ of the respondents think that social media contributes in strengthening democracy. It might be said that participants believe in the power of social media, but they never thought that this power will remain permanent.
\end{abstract}

Keywords: Social organization, social change, social media

\section{Introduction}

Undoubtedly, the basic concept that can be used to define today's world is change. Developments in communication technologies and the globalization that brings the world into an integration process in almost every area are referred to as the locomotives of this change. Even though the speed of the circulation of money, goods and services in the world is not a new thing, the process which is the result of this speed, recorded especially in the last century, is known as globalization. Globalization, in the words of 
Giddens (1991: 66), means to make time free from space such that there are no boundaries for communication, and it cannot be considered separately from developments in communication technologies. While advances in communication technologies have accelerated the diffusion of globalization, they have also been influenced by the outcome of this integration process (Held \& McGrew, 2000: 18). Nowadays, every Internet user has the chance of creating, modifying, interpreting, and evaluating any content. Also, they have the power to become a member of communities that might not even be aware of their existence without using the Internet. New ideas, insights, communities, forms of socialization, and frames of meaning can be developed without a direct physical connection between people. As a consequence of globalization and new communication technologies, reactions in social organization and social movements are growing faster. Also, they are spreading faster across the globe. In this environment, various interventions are needed in order to understand the change that takes place. Social organizations which draw attention to social problems are also of significant importance in the process.

This study aims to understand the importance of social media in organizing the society. However, efforts were made to reveal the opinions of social media users on the role of social media. Social media present a new sphere for social organization in social movements for different parts of society. These media which transform traditional forms of organization announces social problems more quickly and effectively. However, social media have advantages for social organization as well as some disadvantages such as surveillance. Based on the scope of this study, examples of the use of social media tools will be given. Also, advantages and disadvantages of these tools in social organization will be discussed in the context of social change, social movements, characteristics of social media platform such as Facebook for participation and social organization.

\section{Social Change}

Individuals while trying to maintain their daily lives in the society, which may be defined as a complex structure composed of people who have historical, cultural and social relations and also common and behavioral rules, have formed various structures and institutions. As a result, individuals communicate within the relations determined by these structures. Although this communication based structure is not stable, it is dynamic and has a potential of continuous change. In the emergence of this potential, technological changes are as effective as the social and environmental changes. Societies have to adapt to these transformations in their environment in order to sustain their existence. 
Consequently, there is a dynamic structure of the society on the basis of social change which can be defined as a transition from a situation to another situation or formation in social relations and institutions. This dynamism is based on the interaction of all the social structures, relations and people. The change that occurs in the material conditions of the social structure transforms the culture, belief system, values, norms, and other social control means. This means, however, serves as social belonging for people as well as ways of social organization.

We can define social change as "transition to a state or style other than a certain state or entity in social relations, institutions, and structures” at the macro level (Cited; Sunar, 2014: 2). Social change is the significant alteration of the social structure and cultural patterns through time (Harper \& Leitch, 2016:5).

\section{Social Organization}

Castells (2001) points out that problems and crises are what tend to trigger social movements and social change. Social organization which is accepted as solution to social problems might be defined as a voluntary activity focused on helping others, achieving a public good, or solving a community problem (Zukin et al., 2006). This is done in cooperation with others in order to effect change.

Social organization as one of the methods developed to find solutions to social problems aims to solve the social problems and create the social change necessary for this (Kongar, 1971: 119). The First Lane Report published in 1939 in the United States explained that the main goal of the social organization is "to increase people's problem-solving capacity". Although the Report did not provide an agreed and comprehensive definition of social organization, the general objectives of social organization may be listed as follows:

- $\quad$ To discover and define the social needs

- $\quad$ To prevent social problems as far as possible

- To adapt the needs and resources

- $\quad$ To change the resources according to the changing needs

Brody and Nair (2000: 265) mentioned five basic stages of social organization which are investigation, diagnosis, action plan, implementation, and evaluation. The primary activities at the first stage involve the collection of the necessary information and identification of the social problem. It might be stated that a problem should be shared or accepted by the vast majority of the society for social organization and collective action. An individual dissatisfaction might be defined as a social problem when it becomes a commonly felt concern. Therefore, it is necessary to raise 
awareness to define the social problem. Also, media can be useful for this as well as other means like politicians, volunteers, financial supporters, etc.

The foremost groups for social change and social action include people who were affected by the problem and people who have power and status for change. Non-Governmental Organizations (NGOs) which are formed by people who have that problem or to represent those people are another important actor in this process. Therefore, it is difficult to make a clear and valid definition of non-governmental organizations (NGOs) because NGOs are an extremely diverse group of organizations. Also, they can make meaningful generalization very difficult. According to Charnovitz (1997:185), NGOs are groups of individuals organized for the myriad of reasons that engages human imagination and aspiration. de Senillosa (1998) writes that NGOs, which rely on a wide social base, are tied to social movements and influences private and public decision-making by claiming to hold alternative ideologies or values.

Bottomore (1993: 22) defines the social movement as an effort to encourage the change or to resist this change in the society. Melucci (1985: 87) also regards the social movement as one of the dynamics of social change which pushes back the frontiers of the order and the system of the society. Social movements involve a prolonged contestation of authority with interactions between the challengers and powerholders (Tarrow, 1988). This is with the end goal of ultimately achieving some kind of social change.

Notwithstanding, samples of social organizations in Europe and America have been substantially built up from the bottom of the society. These samples include the French Revolution, the Enlightenment, the Boston Tea Party (protest) and so on. In Turkey, efforts were made from the upper classes and it spread from top to the bottom of the society. So at this point, it is important how the social groups should be moved. After two military coups in Turkey, the rights of organization were restricted. Subsequently, there is a social and cultural structure which makes collective action difficult. Under these conditions, social media were presented and accepted as alternative ways for social action.

\section{Social Media}

There is a mutual interaction between social relations and communication. Communication technologies are one of the main factors influencing social change. Similarly, the requirements and rules of social structure can trigger technological developments. The last communication technology is the Internet and it is affected by social needs. Therefore, the Internet has brought new terms into our lives such as new media and social media. 
Kaplan and Haenlien (2010: 61) defined social media as “a group of internet-based applications that build on the ideological and technical foundations of Web 2.0, and that allow the creation and exchange of user generated content.” Miletsky (2010) points out that social media is an inclusive umbrella term including all of the means and applications such as social network sites (SNS), forums, blogs, microblogs, etc. for the purpose of socialization on the Internet. Today, the Internet users have an account at least one of them. Some of the subtitles under the Internet are as follows:

- $\quad$ Forums: Forums are sharing platforms in electronic environment. The foremost element of forums coordinated by a moderator or an administrator is its members who enrich the forum and create interactivity with their sharings.

- Blogs (weblogs): Blogs are interactive structures where written comments are shared under a title. It is a sharing platform for people who have similar ideas and interests.

- Microblogs: Blogs are social media platforms whose data entry space is limited. Twitter, which is the most known, has a limited data entry space of 140 characters sharings.

- Podcasts: This is a digital platforms which a radio broadcast or similar content via the Internet from personal audio recorders is been listened to.

- $\quad$ Wikis: These are websites that can be directly written by any person. As a global encyclopedia that is updated with the entries of users from different countries, wikipedia is one of the best examples.

- $\quad$ Social Tagging Sites: These sites list the links and content shared by users with tags. One of the best known is Foursquare that enables users to share their comments and likes about places.

- Social Networks: Social networks which "create communities on the Internet" (Yağmurlu, 2011: 7) are the most used social media and it provide connections with a wide community. Boyd and Ellison (2007) defined social network sites (SNS) as an online service for users to create a public or semipublic profile, build a network with other users with whom they share a common link, and navigate other users' profiles and networks. We can classify social networks as friendship, business networks, matchmaking networks, graduation networks, and brand social networks (Büyükşener, 2009: 40). The most well-known example of social networks is Facebook, which allows people to communicate and share posts with friends. Social networks are created by people who interact directly or indirectly with each other.

- $\quad$ Media Sharing Sites: Although these sites have same characteristics like membership, profile creation and friendship with other social 
networking sites, the focus of these sites is on sharing a specific type of content (Lietsala \& Sirkkunen, 2008). Youtube is the most used and known media sharing site.

New technologies are a combination of techniques developed earlier. Through new media, the speed has increased, the geographic and demographic coverage has expanded, and the access area has grown. Larger parts of the society might benefit from the speed and the fall of the costs in communication by social media. Thus, individuals might have a chance to break the hegemony of the traditional media's one-sided communication. Lev Manovich (2001) in his book titled The Language of New Media proposes five "principles of new media" as numerical representation, modularity, automation, variability, and transcoding. According to him, variability demonstrates how the changes in media technologies are closely tied up with changes in social organization. "Just as the logic of old media corresponded to the logic of industrial mass society, the logic of the new media fits the logic of the post-industrial society of personal variability. In industrial mass society, everybody was supposed to enjoy the same goods and have the same beliefs. In a post-industrial society, every citizen can construct her own custom lifestyle and select her ideology from a large (but not infinite) number of choices” (Manovich,1999:2)

Consequently, social media differs in some respects from traditional media (Mayfield, 2008):

- Participation: Social media encourages the contribution and feedback of everyone. This blurs the line between the media and the user.

- Clarity: Many social media services are open to participation and feedback, and they encourage the followers to vote, comment, and share information.

- Dialogue: Social media can be seen as a bilateral dialogue when traditional media is related to 'publishing' (transmission or distribution of the content).

- Connectivity: Most types of social media use other sites, resources, and people to enrich their own connection.

- Community: Social media can quickly shape communities and provide effective communication. Communities can share common interest, such as photography, a political issue, or a popular television show.

One of the most important characteristics of new media is interactivity. In a very general definition, interactivity is a sequence of action and reaction (van Dijk, 2006: 8). Jan van Dijk (2006) counts four levels of interactivity from the elementary level where interactivity involves the possibility of establishing two-sided or multilateral communication to the highest level. At this level, interactivity means acting and reacting with an understanding of meanings and contexts by all interactors involved. In the 
third level, interactivity means "that the user is able to intervene into the program or representation itself and to make a difference.” This level needs participation, connectivity and also community. In Mulgan's (1997:1) words, "the world may never have been freer, but it has also never been so interdependent and interconnected."

Social media gives opportunity to individuals to share their own content. For some people, this makes the control decentralized. Through the means of the Internet, news has been freed from the pressure of the patronage. Thus, new communication channels have been opened among the individuals, groups, and societies. "The Internet and SNS are both the result of and the enabling infrastructure for new ways of organizing collective action via communication technology" (Rheingold, 2002: 47). The heterarchical, decentralised and likewise open architecture of the Internet, provides the necessary precondition for virtual communities. Hence, it is used for participation and the emergence of new social movements. "There is no guarantee that networked information technology will lead to the improvements in innovation, freedom, and justice that [...] are possible. That is a choice we face as a society" (Benkler, 2006: 18). Also, NGOs has a more active position than the past via the Internet and SNS. A perpetual problem of social movements has been on how to obtain enough highly motivated individuals to initiate a mobilization. However, it also aims to attract more participants and resources. With SNS, all it takes is a click of the mouse for participants to be recruited globally (Harlow, 2011: 229).

The individual is able to socialize outside the space and time constraints of the public sphere. Physically speaking, intensive definitions such as "being in public sphere", which makes socialization possible, are in mental and physical exchange with virtual intensive definitions such as "being visible in social media" (Eraslan, 2013: 32). Thus, individuals have entered into virtual socialization with friends' circles. With this structure, social media have become major tools used for purposes such as information gathering, communication, education, social interaction, promotion, marketing, shopping and political communication.

\section{Social Media in Social Organization}

Social media is a new channel for social action and social organization. Different segments of the society have begun to use social media in order to reach political power or to be organized by expressing various discomforts and problems. Differentiation of all of the relations and dimensions of the individuals in social and global scales via the Internet and social media means transforms relations of social movements to all traditional concepts, institutions, and methods (Babacan, 2014: 156). 
Movements have been moved to virtual world by means of social media. Also, the limitation of time and space has disappeared; and so global awareness has increased (Yeniç1kt1, 2014: 264). Social networks provide a new public sphere by gathering a large number of people. Civil society movements have now ceased to try to draw the attention of the traditional media to announce their voices. Also, they have begun to guide the communities by establishing their own virtual communities through their own social media tools. It was claimed that social media has given chance to address their ideas for the minorities. Social networks carry the awarenessraising messages quickly and effectively by giving opportunity to intercommunity interaction, mirroring the fact that 'another world is a possible' call in the global and local levels (Karagöz, 2013: 137).

Social media can be viewed as an outstanding power that contributes to the direction of social, political, and cultural developments. It is a means by which people move towards a purpose and share their ideas. Today, social media content is one of the items of the agenda setting meetings of the traditional media. In other words, social media content is also on the agenda of the traditional media.

The Internet and social media also affect political activities. It might be mentioned that there are three functions of the Internet in terms of its potential for political activity. The first one is the "agora” function. Social media is becoming a global arena because of its interactive structure. The other one is organization function for the political activism through decentralized construction of the Internet. The third function is cross-border circulation of the information (Karagöz, 2013: 143). Therefore, these functions are also facilitative in terms of social organization.

Characteristics of information and communication technologies in general and social action in particular include: [1] the foundation for community building, [2] the interrelation of the real and the virtual space, [3] digital divide and social inequalities, and [4] the influence of globalisation on local communities and their contribution to the global public sphere (Neumayer \& Raffl, 2008: 2).

Mark Poster (2001:123) describes the Internet as the 'fruit of second media age' creating a new kind of public sphere, apart from modern standards with postmodern characteristics. Social networks such as Facebook, Twitter, and Youtube are collecting millions of people thereby providing a new public sphere. By means of social networks, undecided people might be included in the organizational process. It is also seen that the protest forms have become widespread and globalized as a result of sharing through new media (Çaycı \& Karagülle, 2014: 6374).

According to di Gennaro and Dutton (2006: 310), the Internet and social media appeal to people who think that governments are not responsive 
to citizens' concerns. At least, since the anti-globalisation movement's adoption of the Internet as a major tool, news media have constantly approached the emergence of any new movement in terms of the technology defining it (Gerbaudo, 2012). Social media makes it easier to organize, allows ideas to spread quickly, and allows people to react more quickly to political or social events by providing instant and speedy communication among the people. Morozov (2007) counted eight (8) strategies which activists can benefit from new media:

- Improve access/quality of information

- $\quad$ Attract public attention to a particular problem

- Facilitate gathering and/or analyzing of data with the help of volunteers

- $\quad$ Establish direct contact with politicians/constituencies

- $\quad$ Improve outreach/attract new members

- $\quad$ Mobilize the movement and help with logistics

- $\quad$ Create new and creative ways for fund-rasing and collective action

- $\quad$ Publish and exchange information with other NGOs and activists

In the context of the new world order in many parts of the world, including Turkey, anti-systemic movements addressed to the people have become popular through "new media”. Social networks place the individuals in the center rather than the subject or the event when compared to other websites and traditional media. Social media platforms Facebook and Twitter are websites which enables the users to mail and communicate. It serves as socialization platforms that allow the people to organize, share information and ideas, and also built groups around similar beliefs. In fact, social media is not one of the causes of political action, whereas societies use it as an organizational and communicational platform in political actions (Joseph, 2011). Social media were used to reach more people in very different political actions such as the Wall Street occupation, the London uprisings, and the Arab Spring. "The fact that the new media enable well-informed citizens, employees and consumers to have more direct communication with, and participation in, institutions of decision-making should, in principle, strengthen democracy. On the other hand, because the technology is susceptible to control from above, democracy could be threatened" (van Dijk, 2006: 3). As a result, we should be reminded that there are some people who warn us about the potential of social media in social organization. For instance, Bauman and Lyon (2013:12) wrote "This is an area to be carefully watched, not least because it is already being surveilled. Social media depend for their existence on monitoring users and selling the data to others. The possibilities for social media resistance are attractive and in some ways fruitful, but they are also limited, both due to the lack of resources for 
binding relationships in a liquefying world and to the fact that surveillance power within social media is endemic and consequential." According to Gary T. Marx (1996) who introduced the concept of surveillance society, surveillance society refers to a situation in which the barriers to total control are destroyed by computer technology. New technologies are constantly increasing the potential for surveillance. Official authorities might monitor much more easily millions of people on the network. Also, in some countries, potential opponents can be identified more easily. Morozov (2011: 113) argues that the Internet and new media might be transformed into the surveillance devices of sovereign power rather than tools for opponents. He agrees on the potential of new media for social mobility, social organization and democratic environment. Thus, he adds: "Don't think that the opponents are using the Internet and the states are only watching." Digital communication technologies not only offer new possibilities, but also lead to new problems or deepen the existing problems in social life. People all across the globe are excluded from possibilities offered by the Internet and related technologies because of imbalanced power relations, lack of purchasing power, exclusion from the process of shaping technologies or commodities, lack of relevance for the market, access, skill or capabilities. Most of the world does not have regular access to the Internet (Norris, 2004). The potential of accessing the Internet and the fear of exclusion were subsumed under the term "digital divide". This focuses on the gap between haves and have-nots. Authors such as Couldry (2007) points out that simply providing access will not lead to global activism, participation, or social equality. "New orientation could be characterized as the shift from building infrastructure to creating identities, i.e. from bridging the digital divide to closing the knowledge gap” (Maier-Rabler, 2002: 15).

New media may give opportunity for new political opposition or political participation. However, these forms of organization and activity are rarely carried out in everyday life and their effect is negligible. Moreover, such mobility creates an assumption that individuals have developed an appropriate response to their identities, political views, and positions. It also has a pseudo opposition feeling which has the possibility of motivating real political actions.

Another problem about social media is fictitious profiles to protect privacy. Nevertheless, privacy is not the only reason for this. Other reasons for fictitious profiles might be counted as acting freely by creating false identities, making easier surveillance by hidden identities or feeling of satisfaction by unlimited power (Uyanık, 2013). This fictiveness and anonymity in social media also bring about the rapid spread of disinformation. This false or falsified information, which we can refer to as "fake news", constitutes a disadvantage in the studies of social organization. 
In the study of Allcott and Gentzkow (2017) which reveals the influence of fake news spreading rapidly through social media on people in 2016 US presidential elections, "fake news" is defined as "news articles that are intentionally and verifiably false, and could mislead readers.”

\section{Method and Data Collection}

The aim of the study is to seek an answer to the question of "Do social media users believe in the role and importance of social media in social action and social organization?” Data for the study was collected by an online questionnaire. At the preparation stage of the questionnaire, a literature review was made primarily and similar studies were examined.

The research population of the study was Facebook users in Turkey. The sample of the study is convenience incidental sampling which is based on the researcher's choice of a piece of the universe in any way according to the size of the indicated sample (Arl1 \& Nazik, 2001: 75). In this sampling method due to various limitations, easily accessible and feasible units of population were selected.

According to Digital in 2017 Global Overview Report, there are nearly 48 million active social media users in Turkey. According to the formulation for the population and sample size that can be represented with 0.95 reliability and 0.05 sampling error, sample size of 384 persons for 1 million or more population has been proposed (Yazıcıoğlu \& Erdoğan, 2004: 49). Taking into consideration these figures and also the fact that the possibility of all the surveys may not be returned, a sample of 500 Facebook users has been identified. Surveys were sent via Facebook to the researchers's friend lists. 448 questionnaires were returned with the answers. Therefore, it might be stated that the research sample is adequate. Data were collected from Facebook users through a survey that consists of a total of 11 questions. The survey was conducted between the dates of 06-13 March 2017. It took approximately 15 to 20 minutes to answer the questionnaire. The preliminary survey was made for the efficiency of the content and the sufficiency for the analysis of 10 people who had Facebook accounts. Participants answered the questions about their demographic information (e.g. age and gender) and also their activity on the Internet. Participants were asked to evaluate 13 expressions regarding the role of social media in the social organization such as "Social media are platforms where opinions can be freely shared on social issues", "Social media empower democracy", and "I believe that organized groups via social media will be permanent". This was to be done using a five-point Likert scale from " $1=$ stronly agree" to " $5=$ stronly disagree". Finally, it was asked "what is the first example that came to mind about the active use of social media in social organization?” 
Facebook is one of the most preferred social media site in Turkey like lots of countries in the world. Facebook has been used to mobilize individuals to participate in protests around the globe. It is possible to set up social groups easily on Facebook. Facebook users and their social networks provide an easily and instantaneously accessible critical mass. It seems likely that Facebook, due to the ability of users to easily expand and maintain large networks, is positioned to facilitate online engagement because its feature-set (e.g., the "newsfeed" and user "wall") acts as mechanisms to support the individual's participation. Popular applications of Facebook allow anyone with shared interests to become a 'fan' or join a 'group' and participate in discussion forums and threads. Facebook-specific research has examined the use of the network in the development of social action and online community and found positive effects (Ellison et al., 2006). Due to the above mentioned reasons, it is believed that Facebook would be an appropriate choice for the study.

\section{Results and Discussion}

According to the results, 41\% (184) of the individuals who responded to the questionnaire were females and 59\% (264) of them were males. 56\% of the participants are between the age of 18-25, 22\% of participants are between the ages of $26-35$, and $18 \%$ of the participants are between $36-45$ years. The proportion of the participants under 17 years old and over 45 years is $4 \%$. It is possible to claim that the reason behind the high rate of the young participants is the distribution of the questionnaire forms via social media. Most possibly due to the same reason, $72 \%$ the participants have university degree and 18\% have master's degree. Others (approximately $10 \%$ ) have pimary, secondary, and high school degrees. When we look at the distribution of the participants according to occupations, the students have the biggest rate with $55 \%$. In addition to $22 \%$ of private sector employees, $14 \%$ civil servant contributed to the study. According to the results, there was no significant difference on the usage of social media depending on education level or occupation. Taking a look at the frequency of the Internet on social media platforms, it has been seen that $93 \%$ of the participants spend more than 2 hours per day. While 26\% of those aged 45 over use the Internet under one hour, there are no internet users under one hour per day at the age group of 17 and under. In addition, the smart phone as a means of access to social media ranks first with $66 \%$.

The participants of social media platforms most frequently use Facebook and Twitter with the rate of $81 \%$ and $57 \%$ respectively. Video sharing site Youtube is also much preferred with the rate $90 \%$ according to our results. $86 \%$ of the respondents said they became members of the social media groups they like. $50 \%$ of the participants also invited their friends to 
the social media groups they like. Also, 34\% of respondents stated that they formed a new group on Facebook. In addition to those who use social media sites to socialize, shop, research, and follow up invitations to the events, $82 \%$ of respondents stated they follow the announcements about social actions on Facebook.

When they were asked about the first example of active usage of social media in social organization, 53,7\% of respondents expressed Taksim Gezi Park Protests and 20,9\% of participants gave the example of the events after 15th July coup attempt. While $16,9 \%$ of the participants gave the example related woman's movements, 5,8\% of the participants cited the Arab Spring. The "Other” item which joins the different answers such as sports events, advertisements, social assistance, and solidarity campaigns and public walks against terrorist attacks is about 3\%. Results about active use of social media in social organization were shown in Table 1.

Table 1. Examples of Active Use of Social Media in Social Organization

\begin{tabular}{|c|c|c|}
\hline Examples & Frequency & Percentage (\%) \\
\hline Gezi Park Protests & 241 & 53,7 \\
\hline 15th July & 94 & 20,9 \\
\hline Woman's Rights & 76 & 16,9 \\
\hline Arap Spring & 26 & 5,8 \\
\hline Other & 11 & 2,7 \\
\hline Total & 448 & 100 \\
\hline
\end{tabular}

Considering the fact that about 54\% of the respondents stated Taksim Gezi Park Protests as the first case that came to their minds about using social media in social organization, the effect of this event even 4 years later was seen. The lack of time and space in the preparation and presentation of the message, the speed of reaching the target groups, and the ability to react instantly to the targeted audience has make social media an easy to use and effective means of propaganda. According to a research, 69\% of Taksim Gezi Park activists said that they heard the events from social media (Yeniçıktı, 2014: 275). Social media got ahead of the mainstream media in many occasions such as organizing of the users, helping and informing each other about the events in Gezi Park Protests (Topbaş \& Işık, 2014: 219). Subsequently, becoming a means of disinformation in the later days of the movement revealed the disadvantage of social media in social movements. At this point, information pollution in social media needs attention.

It might be possible to evaluate the events in the night of 15th July based on the scope of the role of social media in organizing the society. On the 15th of July 2016, according to the information shared by the mainstream media, a group wanted to make a military coup by communicating through WhatsApp which is a social media tool (www.milliyet.com.tr/darbecilerinwhatsapp-konusmalari-gundem2279798). The coup attempt has taken place 
simultaneously on the agenda of the social media as well as the traditional media news flow. A few hours after the attempt, the President connected to a national news channel via FaceTime. After he made a call to the public, a new mobility started in social media means. Anti-coup people have been organized through social media, too. As a result, both parties benefited from the social media for the purposes of organizing. On July 15th, Twitter for instant information flow, FaceTime for video conversation and WhatsApp for mass communication became the most important social media tools (http://www.ahaber.com.tr/teknoloji/ 2016/09/14/15-temmuzda-en-coktwitter-uzerinden-haberlesildi). This event has been given as an example by about $21 \%$ of the survey participants.

Third example which is given by $17 \%$ of the participants for active use of social media in social organization is woman's rights campaigns. Karatay and Karatay's (2015) study on social media campaigns on violence against women argues that social media contributes to social movements. This was seen from the examples of UN Women's campaign with the slogan "I am wearing Orange." This campaign was held by the personal care brand, AVON and One Billion Rising, for raising the awareness of violence against women. Successful social media campaigns have been carried to traditional media channels and their effects are bigger in public opinion.

$40 \%$ of the respondents stated that they agree that the expression of "Social media contributes to strengthen democracy". As seen in the example of the Arab Spring, opportunities provided by new technologies make it easier for the social organization (Yeniçıktı, 2014: 274). In our study, 6\% of respondents gave the Arab Spring as the example for the use of social media in social organization. Social media was a very important tool in organizing the Arab Spring, but newness and diversity of social media means around the world do not provide satisfactory data to prove an important assumption. However, "these tools have led to social revolutions". It can be argued that social media facilitates social organization as the supporting means to social movements rather than creating change. The rapid increase of Facebook and Twitter users in the Arab countries during the social mobility has showed the importance of social media as a "tool" for social movements. However, in order to understand the social movements and mobility of these countries, it is necessary to look at the background of the events and the sociological structure of the countries (Babacan et al., 2011: 79). Although online participation has not automatically brought the offline activities such as putting up stickers or wearing support bracelets or collective action, Calenda and Meijer (2009) pointed out that online participation is a strong trigger on offline participation. Another example of the use of social media for social organization is the campaign launched by Greenpeace in 2012 against the world famous clothing brand, Zara. This made a huge impact within a very 
short time (8 days). The supportive power of this movement was also social media. Therefore, at the end of the campaign, Zara stepped back and promised to remove toxic chemicals from its products until 2020 (www.greenpeace.org/turkey).

It might be said that social media has become an important means for NGOs. Survey respondents with a rate of $57 \%$ also think that social media increases the power of NGOs. Shirky (2011) who is an optimist about the democratic role of social media, points out that if activists use social media efficiently, it can result in political and social change because people think "they can". van Laer and van Aelst (2009) argue that the Internet gives alternative ways for collective action. As a result, it has an important role for new social movements. Clay Shirky in his book Here Comes Everybody (2008) argues that social media has new tools that enables new forms of group formation. These new tools are making our lives easier and making our communication faster and faster, that is, invariably better. Thus, 'as more people adopt simple social tools, and as those tools allow increasingly rapid communication, the speed of group actions also increases' (Shirky, 2008: 161). Examples present the social media's advantages in the context of social organization such as easy access, rapid communication, lack of space boundaries, reach the large masses, immediate response, and so on. At this point, it is worth noting that about $50 \%$ of our survey participants think that social media is a platform where opinions can be freely shared in social issues, and that participants think social media has increased the power and importance of the individuals and also societies. $72 \%$ of respondents think that social media is a powerful tool in organizing social actions. $73 \%$ of the participants agree on the expression of "Social media might be used to move social problems to the public agenda more rapidly". Therefore, these ratios indicate that the majority of survey participants prioritize the advantageous sides of social media in organizing society.

Social media might be viewed as an endless free environment. Contrary to what is supposed to be, these tools are not independent of balance of power. This is the case because new media may not only have the potential of a starting point for dissenting voices, but also may become an instrument of pressure and totalitarian regimes (Karagöz, 2013: 139). In the scope of the study, survey participants were asked to evaluate the expression "I believe that social media should be censored by the state during periods of social action". Thus, $56 \%$ of the participants stated that they do not agree to this expression.

According to its supporters, the Internet is an important tool in the development of democracy because it increases participation. However, according to opponents, the Internet increases the propaganda and 
surveillance possibilities of the states as well as creating the illusion that people do an act by a "like" or a "tweet". Some researchers like Hindman (2009), Morozov (2009), and Putnam (2000) warned about exaggerated role of the Internet on democracy and collective action. Morozov (2009) argues that for a lazy generation, digital activism or with his words "slacktivism" is an easy and comfortable way of pretending to care about political and social matters. "Slactivism" is derived from "slacker" which means lazy, while "activist" means participates on the social action. However, they represent a supporter's participation with a little effort for a social issue or problem including signature campaigns on the Internet. In his book The Net Delusion (2011), Morozov criticises techno-optimistic visions holding that 'technology empowers the people who, oppressed by years of authoritarian rule, will inevitably rebel mobilising themselves through text messages, Facebook, Twitter, and whatever tool comes along each year' (Morozov, 2011: xii). As Morozov notes, social media like Twitter and Facebook are mostly used for entertainment purposes, for sharing one's own daily doings rather than for political organising. Reaction might be demonstrated with just one click, a like or a message on the Internet. Hence, a lot of people do them only for "keeping up with the times". So many internet activists (slacktivist or clicktivist) are not really aware of what or why they support or why they are opposed (Petras, 2011: 21).

Fake identities created through social media can be used for manipulation during social movements. The virtual communities created by the Internet activists are supportive in social organization. Thus, they are artificial and dispersible easily. At this point, as opposed to traditional social organization studies, in social media campaigns, goals which might be reached in the short run are set. Due to this, the potentials of the groups for reaching their goals and disbanding are high. There are no strong bonds between these communities formed on the Internet, such as friendship and companionship. These bonds becloud to separate the group (Karagöz, 2013: 145). Our result on this subject confirms this finding. The proportion of participants who think that the groups organized in the social media are effective is $47 \%$, while the percentage of those who believe that these groups will be permanent is $24 \%$. Participants believe in the power of social media organization but their beliefs are weak about the continuity of these groups. Members are not deeply dedicated in social movements any more. Therefore, while a movement's support might grow quickly initially, that support is likely to soon fall off (Diani, 2000). Galston (2000) points out that online participation structures are not stable and long standing. Garrett (2006: 211) indicates that one of the reasons for this situation is that "participants know that when another need arises, another group can be built up again quickly and easily". New media facilitate faster and more effective dissemination of 
the ideology. Thousands of people can pour into streets and return to their houses so quickly.

Social media means are open to all interactions, unlike traditional means of communication. However, this feature creates an environment in which individuals can freely express their ideas. It also makes them "easily manipulatable, provable, and misleading”. As a consequence, a social movement that has been justifiably initiated can become misleading by the purpose of "social media”. Thus, this is one of the biggest problems of new social movements after social media starts losing its clarity about purpose, aim, meaning, and content. Also, it replaces it in a more blurry, uncertain, and identityless situation.

\section{Conclusion}

The individuals who try to maintain their lives in society communicate within the framework of relations. These relations are, however, defined by the structures and institutions that they established before. This communication based structure is of course dynamic and has the potential of continuous change. Nowadays, it is important to examine social media as one of the factors that affect social change or social structure. Social media, which provides users with an interactive environment by sharing information, ideas, images, etc., has some different features than traditional media such as high speed, cheapness, participation, interaction, removing the time and space borders, individual use possibility, creating a new public space, facilitating organizing for the communities, giving opportunity for representation of different groups and access to information, and so on.

There are some successful examples of the use of social media as a means in social organization. Of course, the only factor here is not the use of social media. There are some other factors which affect the success of organizing such as social construction, the size of the mass that shares the problem, the social problem that causes the organization of society and its background etc. The Arab Spring, Gezi Park Protests, coup attempt on 15th July, the campaigns of international organizations like Greenpeace, and the campaigns on sites like change.org are examples of the role of social media in social organization. In all these social actions, social media has undertaken an important role in planning, organizing, and campaigning as a tool. Yet, social media has characteristics that facilitate social organization. It has some disadvantages that should be taken into account for evaluation such as the use of a propaganda apparatus. Another disadvantage is the potential for dissolution of social groups within a short time. Another point that needs to be emphasized is that social media is open to manipulation. Sharings made 
through the creation of false identities can cause social organization to move out of its intended purpose.

Social media has many characteristics that can lead to advantages or disadvantages in social organization. In our study, $72 \%$ of respondents agree that social media is a powerful tool in organizing social actions. In addition, the rate of respondents who agree with the expression of "Social media might be used for handling the social problems on the public agenda" is $73 \%$. These ratios indicate that the vast majority of the study respondents are preoccupied with social media's advantageous sides in organizing society.

\section{References:}

1. Allcott, H. \& Gentzkow, M. (2017). Social Media and Fake News in the 2016 Election. Cambridge: National Bureau of Economic Research.

2. Arl1, M. \& Nazik, H. (2001). Introduction to Scientific Research (Bilimsel Araştırmaya Giriş). Ankara: Gazi Kitabevi.

3. Babacan, M. E. (2014). New Social Movements after Social Media. Journal of Individual and Society (Birey ve Toplum Dergisi), 4 (7), 135-160.

4. Babacan, M. E., Haşlak, I., \& Hira, I. (2011). Social Media and Arab Spring. Journal of Academic Review (Akademik Incelemeler Dergisi), 6 (2), 63-92.

5. Bauman, Z. \& Lyon, D. (2013). Liquid Surveillance. Cambridge: Polity Press.

6. Benkler, Y. (2006). The Wealth of Networks. How Social Production Transforms Markets and Freedom. London: Yale University Press.

7. Bottomore, T. (1993). Political Sociology. London: Pluto Press.

8. Boyd, D. M. \& Ellison, N. B. (2007). Social network sites: Definition, history and scholarship. Journal of Computer-mediated Communication, 13 (1), 210-230.

9. Brody, R. \& Nair, M. D. (2000). Macro Practice A Generalist Approach. Wheaton, IL: Gregory Publishing.

10. Büyükşener, E. (2009). The Place of Social Networks and Social Media Review in Turkey. Proceedings of XIV. Conference on Internet in Turkey (Türkiye'de Internet Konferansi). 12-13 December, Istanbul: Bilgi Üniversitesi, 39-43.

11. Calenda, D. \& Meijer, A. (2009). Young People, the Internet and Political Participation: Findings of a Web Survey in Italy, Spain and The Netherlands. Information, Communication \& Society, 12 (6), 879-898.

12. Castells, M. (2001). The Internet Galaxy: Reflections on the Internet, Business and Society. Oxford: Oxford University Press. 
13. Charnovitz, S. (1997). Two Centuries of Participation: NGOs and International Governance. Michigan Journal of International Law, 18 (2): 183-286.

14. Couldry, N. (2007). Communicative Entitlements and Democracy. In R. Mansell, C. Avgerou, D. Quah \& R. Silverstone (Eds.), The Future of the Digital Divide (pp. 383-403). Oxford: Oxford University Press.

15. Çaycı, B. \& Karagülle, A. E. (2014). Organizational Forms Which Covaries With Mobile Communication Technologies: Social Movements Which are Organized in Networks. Journal of Yasar University, 9(36), 6371-6380.

16. de Senillosa, I. (1998). A new age of social movements: A fifth generation of non-governmental development organizations in the making? Development in Practice, 8 (1), 40-53.

17. di Gennaro, C. \& Dutton, W. (2006). The Internet and the Public: Online and Offline Political Participation in the United Kingdom. Parliamentary Affairs, 59 (2), 299-313.

18. Diani, M. (2000). Social movement networks virtual and real. Information, Communication \& Society, 3(3): 386-401.

19. Ellison, N., Steinfield, C. \& Lampe, C. (2006). Spatially Bounded Online Social Networks and Social Capital: The Role of Facebook. Paper presented at Annual Meeting of the International Communication Association, 19-23 June, Dresden, Germany. Retrieved on June 07, 2017 from https://www.msu.edu/ nellison/Facebook_ICA_2006.pdf.

20. Eraslan, R. U. (2013). Social Media: Being Visible in Everywhere and Every Moment. The Turkish Online Journal of Design, Art and Communication - TOJDAC, 3 (4), 29-37.

21. Galston, W. A. (2000). Does the Internet Strengthen Community? National Civic Review, 89, 193-202.

22. Garrett, R. K. (2006). Protest in an Information Society: A Review of Literature on Social Movements and New ICTs. Information, Communication \& Society, 9 (2), 202-224.

23. Gerbaudo, P. (2012). Tweets and The Streets: Social Media and Contemporary Activism. London: PlutoPress.

24. Giddens, A. (1991). The Consequences of Modernity. CA, Stanford: Stanford University Press.

25. Global Overview

Report. https://wearesocial.com/uk/blog/2017/01/digital-in-2017-globaloverview. Retrieved on April 19, 2017. 
26. Harlow, S. (2011). Social media and social movements: Facebook and an online Guatemalan justice movement that moved offline. New Media \& Society, 14 (2), 225-243.

27. Harper, C. \& Leitch, K. (2016). Exploring Social Change America and the World. New York: Routledge.

28. Held, D. \& Mcgrew, A. (2000). The Great Globalization Debate: An Introduction. In D. Held \& A. McGrew (Eds.), The Global Transformations Reader (pp. 1-45). London: Blackwell.

29. Hindman, M. (2009). The Myth of Digital Democracy. Oxford: Princeton University Press.

30. http://www.milliyet.com.tr/darbecileri-twitter-ve-facetime-gundem2311005/.

31. https://www.change.org/. Retrieved on April 19, 2017.

32. https://www.greenpeace.org/turkey/tr/news/basardik-zara-zehirdenarindirilmis-cagrimizi-duydu-281112. Retrieved on April 23, 2017.

33. Joseph, S. (2011). Social Media, Human Rights and Political Change. Boston College International \& Comparative Law Review, Winter, 35 (1), 145-188.

34. Kaplan, A. \& Haenlien, M. (2010). Users of the World, Unite! The Challenges and Opportunities of Social Media. Business Horizon, 53, 59-68.

35. Karagöz, K. (2013). Changed Social Movements in New Media Age and Digital Activisim. Communication and Diplomacy, 1, 131- 157.

36. Karatay, A. \& Karatay, A. (2015). In the Context of Social Responsibility, 'No Violence Against Women' Social Media Campaigns and Examples of Activism in the World. Uşak University Social Sciences Journal (Uşak Üniversitesi Sosyal Bilimler Dergisi), 8 (1), 21-35.

37. Kongar, E. (1971). Social Development and Social Organization. Journal of Public Administration (Amme İdaresi Dergisi), 4, 116141.

38. Lietsala, K. \& Sirkkunen, E. (2008). Social Media: Introduction to the Tools and Processes of Participatory Economy. Tampere, Finland: University of Tampere.

39. Maier-Rabler, U. (2002). Cultural Aspects and Digital Divide in Europe. Medien Journal, 3, 14-32.

40. Manovich, L. (2001). The Language of New Media. MIT Press.

41. Manovich, L. (1999). New Media: A User's Guide. Retrieved on June 20, 2017 from http://manovich.net/content/04-projects/026-newmedia-a-user-s-guide/23_article_1999.pdf. 
42. Marx, Gary T. (1996). Privacy and Technology, Telektronik January. Retrieved on June 06, 2017 from http://web.mit.edu/gtmarx /www/privantt.html.

43. Mayfield, A. (2008). What is Social Media? iCrossing. Retrieved on April 20, 2017 from http://www.icrossing.com/uk/sites/default/files_uk /insight_pdf_files/What\%20is\%20Social\%20Media_iCrossing_ebook .pdf.

44. Melucci, A. (1985). The Symbolic Challenge of Contemporary Movements. Social Movements, 52 (4), 789-816.

45. Miletsky, J. (2010). Principles of Internet Marketing: New Tools and Methods for Web Developers. Canada: Cengage Learning.

46. Morozov, E. (2007). How can activists and NGOs benefit from new media? Presented at New Media Essentials Summer School on 12.07.2007, Prague. Retrieved on April 23, 2017 from https://www.slideshare.net/evgeny. Morozov/activism-and-newmedia-introduction.

47. Morozov, E. (2009). The Brave New World of Slacktivism. Foreign Policy. Retrieved on April 22, 2017 from http://neteffect.foreignpolicy.com/posts/ 2009/05/19/the_brave_new_world_of_slacktivism.

48. Morozov, E. (2011). The Net Delusion: The Dark Side of Internet Freedom. New York: PublicAffairs.

49. Mulgan, G. (1997). Connexity: How to Live in a Connected World. London: Chatto \& Windus.

50. Neumayer, C. \& Raffl, C. (2008). Facebook for Global Protest: The Potential and Limits of Social Software for Grassroots Activism, Paper presented at Community Informatics Conference: ICTs for Social Inclusion: What is the Reality?(Prato 2008), 27-30 October, Prato, Italy. Retrieved on June 07, 2017 from http://cirn.infotech.monash.edu/assets/docs/ prato2008papers

51. /raffl.pdf.

52. Norris, P. (2004). The Digital Divide: The Information Society Reader. In F. Webster (Ed.), Information Society Reader (pp. 273286). New York: Routledge.

53. Petras, J. (2011). Social Opposition in the Age of Internet: Desktop "Militants" and Public Intellectuals. New Jersey: Balgrave.

54. Poster, M. (2001). What's the Matter with the Internet. Minneapolis: University of Minnesota Press.

55. Putnam, R. D. (2000). Bowling Alone: The Collapse and Revival of American Community. New York: Simon \& Schuster. 
56. Rheingold, H. (2002). Smart Mobs. The Next Social Revolution. Cambridge, MA: Perseus Books.

57. Shirky, C. (2008). Here Comes Everybody: The Power of Organizing Without Organizations. New York: Penguin Press.

58. Shirky, C. (2011). The Political Power of Social Media. Foreign Affairs, 90 (1), 28-41.

59. Sunar, L. (2014). Explaning Social Change: Basic Concepts and Theories (Toplumsal Değişimi Açıklamak: Temel Kavram ve Kuramlar). In L.Sunar (Ed.), Social Change in Turkey (Türkiye'de Toplumsal Değişim) (pp. 1-36). Ankara: Nobel Yayınları.

60. Tarrow, S. (1988). Power in Movement. Cambridge: Cambridge University Press.

61. Topbaş, H., Işık, U. (2014). Gezi Park Protests and Social Media Between Fiction and Reality. Journal of Individual and Society (Birey ve Toplum Dergisi), 4 (7), 197-230.

62. Uyanık, F. (2013). Social Media: Fictionality and Privacy (Sosyal Medya: Kurgusallik ve Mahremiyet). Proceedings of New Media Conference. 7-8 May, Kocaeli: Kocaeli University. Retrieved on June 06 , 2017 from http://s3.amazonaws.com/academia.edu.documents/31610736/SOSY AL_MEDYA_KURGUSALLIK_VE_MAHREMIYET.pdf.

63. van Dijk, J. (2006). The Network Society: Social Aspects of New Media. London: Sage.

64. van Laer, J. \& van Aelst P. (2009). Cyber-protest and Civil Society. In Y. Jewkes \& M. Yar (Eds.), Handbook on Internet Crime (pp. 230-254). London: Willan Publishing.

65. Yağmurlu, A. (2011). Public Relations and Social Media in Public Administration. Selcuk Communication Journal (Selcuk Iletişim Dergisi), 7 (1), 5-15.

66. Yazıcıoğlu, Y. \& Erdoğan, S. (2004). SPSS Applied Scientific Research Methods (SPSS Uygulamalı Bilimsel Araştırma Yöntemleri). Ankara: Detay Yayıncilık.

67. Yeniçıktı, N. T (2014). Communicative Action and Facebook: Power of Social Media in Gezi Park Protests. Selcuk Communication Journal (Selcuk İletişim Dergisi, 8 (2), 263-284.

68. Zukin, C., Keeter, S., Andolina, M., Jenkins, K. \& Delli Carpini, M. X. (2006). A New Engagement, Political Participation, Civic Life, and the Changing American Citizen. New York: Oxford University Press. 